\title{
Head and Neck Cancers in Developing Countries
}

\author{
Poonam Joshi, M.S., Sourav Dutta, M.S., Pankaj Chaturvedi, M.S., F.I.C.S., \\ F.A.I.S., M.N.A.*, and Sudhir Nair, M.S., M.Ch. \\ Head and Neck Surgery, Tata Memorial Hospital, Mumbai, India
}

\begin{abstract}
Head and neck cancers are the most common cancers in developing countries, especially in Southeast Asia. Head and neck cancers are more common in males compared to females. This is mainly attributed to tobacco, areca nut, alcohol, etc. Oral cancers are most common amongst all head and neck squamous cell cancers (HNSCC). HNSCC in the developing world differ from those in the Western world in terms of age, site of disease, etiology, and molecular biology. Poverty, illiteracy, advanced stage at presentation, lack of access to health care, and poor treatment infrastructure pose a major challenge in management of these cancers. The annual GDP (gross domestic product) spent on health care is very low in developing countries compared to the developed countries. Cancer treatment leads to a significant financial burden on the cancer patients and their families. Several health programs have been implemented to curb this rising burden of disease. The main aims of these health programs are to increase awareness among people regarding tobacco and to improve access to health care facilities, early diagnosis, treatment, and palliative care.
\end{abstract}

KEY WORDS: Developing countries, head and neck cancers, health infrastructure, human papillomavirus, tobacco

\section{INTRODUCTION}

World-wide, the head and neck cancers form the sixth most common cancer. ${ }^{1}$ Head and neck cancer

(HNC) is the most common cancer in developing countries. ${ }^{2}$ It is the most common cancer of males in

\footnotetext{
Abbreviations: GDP, gross domestic product; HNC, head and neck cancer; HNSCC, head and neck squamous cell cancers; HPV, human papilloma virus; OSMF, oral submucous fibrosis.

Citation: Joshi P, Dutta S, Chaturvedi P, Nair S. Head and Neck Cancers in Developing Countries. Rambam Maimonides Med J 2014;5 (2):e0009. doi:10.5041/RMMJ.10143

Copyright: (C) 2014 Joshi P, et al. This is an open-access article. All its content, except where otherwise noted, is distributed under the terms of the Creative Commons Attribution License (http://creativecommons.org/licenses/by/3.0), which permits unrestricted use, distribution, and reproduction in any medium, provided the original work is properly cited.

Conflict of interest: No potential conflict of interest relevant to this article was reported.

* To whom correspondence should be addressed. E-mail: chaturvedi.pankaj@gmail.com
} 
India and the fifth most common in females. ${ }^{3} \mathrm{HNC}$ form $21 \%$ of the cancers in males and $11 \%$ in females in Pakistan. ${ }^{4}$ In India, the age-adjusted rates among females is the highest. 5

While head and neck cancers form one of the most common cancers in South and Southeast Asian countries, they form only $1 \%-4 \%$ of all cancers in the Western world. ${ }^{6}$ Oral cancers are predominant forms of head and neck squamous cell cancer (HNSCC) in India, Pakistan, and other Southeast Asian countries; oropharyngeal and tongue cancers are common in the Western world. 4 These differences in site of disease may be related to the prevalent habits in the respective regions. 5

\section{RISK FACTORS}

Cigarette-smoking and alcohol consumption are the main reasons for HNSCC in the Western population, whereas the use of smokeless tobacco and areca nut is the most common cause of HNSCC in Southeast Asia. 7,8 The various forms in which smokeless tobacco is used in developing countries include khaini, mava, paan (betel quid), zarda, snuff, mashiri,etc. ${ }^{9}$

Betel quid chewing is the most common form of tobacco chewing in the Asia-Pacific region. Betel quid consists of areca nut, betel leaf, catechu, and slaked lime. ${ }^{10}$ It has been reported from many countries like India, Pakistan, Bangladesh, Sri Lanka, Thailand, Cambodia, Malaysia, Indonesia, China, Philippines, Taiwan, Vietnam, and migrant populations in Europe, Africa, North America, and Australia. ${ }^{11}$ About $10 \%$ of the world's population chew betel quid regularly. ${ }^{12}$ In one study conducted in Southeast Asia, the lower socio-economic groups had higher risk of developing HNC. ${ }^{13}$

Areca nut alone is a confirmed carcinogen and causally associated with a premalignant condition called oral submucous fibrosis (OSMF) and oral cancer. ${ }^{14}$ It is a chronic, debilitating disease of the aerodigestive tract owing to irreversible fibroelastic changes in the lamina propria which lead to stiffness of the oral mucosa resulting in progressive trismus. ${ }^{15}$ This is uncommon in the Western world due to the rarity of areca nut use. In India alone, 5 million people ( $0.5 \%$ of the population of India) have OSMF. It is considered a public health issue in India, South Africa, and many Southeast Asian countries. ${ }^{16}$

Tobacco consumption in India is growing at a rate of $2 \%-3 \%$ per annum. ${ }^{17}$ Tobacco use is expected to cause 8.4 million deaths by 2020 , and $70 \%$ of these will be in developing countries. In 2010, about 930,000 deaths were estimated to be attributable to tobacco in India. ${ }^{18}$ The high prevalence of tobacco usage has led to increases in disease burden and high health care costs in developing countries. There is a high incidence of smoking reported amongst youth from Bangladesh, India, and Indonesia. ${ }^{19}$ While the incidence of head and neck cancers is decreasing in Europe and North America, it remains unabated in the developing world. ${ }^{20}$

In India, nearly two-thirds of patients present with advanced stages. ${ }^{13,21}$ The mean age of patients at presentation of head and neck cancers is the fifth and early sixth decades in Asian populations compared with the seventh and eighth decades in the North American population. ${ }^{22-26}$

\section{HUMAN PAPILLOMAVIRUS (HPV) PREVALENCE}

The overall prevalence of HPV in HNSCC is around $50 \%,{ }^{27}$ with the highest prevalence in cancers of the tonsil and base of tongue. ${ }^{28}$ The rise in HPV-related cancers has been mainly attributed to the change in sexual practices in the Western world. These patients are younger, have bulky nodes, predominantly oropharynx involvement, equal gender distribution, and have better survival. ${ }^{29-31} \mathrm{HPV}-16$ is the most common type, being present in 30.9\% of oropharyngeal carcinomas, $16 \%$ of oral cancers, and $16.6 \%$ of laryngeal cancers. Prevalence of HPV in oral cancers is similar in Europe (16\%) and North America (16.1\%), but greater in Asia (33\%). ${ }^{32}$

The HPV prevalence in India ranges from $33.6 \%$ in the Eastern region to $67 \%$ in South India and $15 \%$ in Western India.33,34 The prevalences of HPV-6, HPV-11, HPV-16, and HPV-18 were $13 \%, 20 \%, 42 \%$, and $47 \%$, respectively. $33 \mathrm{HPV}-16$ was most common, followed by HPV-18 and then cross-infection (16 and 18$) ; 41 \%$ of patients had multiple HPV infections.33 Lesions of the tongue had the highest rate (9 of 11) of HPV infection. Another study showed a rate of HPV infections of $56.3 \%$ in cancers of the mandible, $37.5 \%$ in cheek, and $38.6 \%$ in maxilla. The study also reported that the advanced stages (III, IV) had higher infection rates as compared to earlier stage. 35

The vaccination of HPV has not been incorporated in the national immunization program of India. There is no evidence to show that HPV vaccination may prevent HNSCC. 


\section{MOLECULAR BIOLOGY OF HEAD AND NECK CANCERS}

Between developed and developing countries, there are not only differences in the age, subsite, and habit but also in the molecular biology. The prevalence of the p53 mutation is common in Europe and USA but rare in India. The recent data show the prevalence to be $81 \%$ in the Western world. Multiple genetic abnormalities are common in head and cancers in India and Southeast Asia. These include a preponderance of Ha-ras mutations (35\%), loss of heterozygosity of Ha-ras (30\%), N-ras amplification (28\%), and N-myc amplification (29\%). These mutations in ras oncogenes are uncommon in the Western world. ${ }^{6}$

\section{HIGH INCIDENCE RATES IN INDIA}

The leading cause of death in males is cancers of the oral cavity, lungs, esophagus, and stomach. In females, the most common site is uterine cervix, breast, and oral cavity. The Cancer Atlas project by the Indian Council for Medical Research (ICMR) has shown the incidences of various cancers in different parts of India. 37 Aizawl district in the northeastern state of Mizoram has the world's highest incidence of cancers, in men, of the lower pharynx (11.5 per 100,000 people) and the tongue (7.6 per 100,000 people). Pondicherry has one of the highest incidences of mouth cancer in the world among males (8.9 per 100,000), and Kohima, the capital city of another northeastern state, Nagaland, has the world's highest incidence of nasopharyngeal cancers. 38,39

\section{CHALLENGES IN HEALTH CARE}

The number of health care institutes dedicated to cancer care is woefully inadequate when compared with Western countries. There are 27 dedicated cancer hospitals (regional cancer centers), and there are about 300 more general or multispecialty hospitals which give cancer care to the patients. $4^{\circ} \mathrm{In}$ the year 2010, India spent only $3.7 \%$ of its gross domestic product (GDP) on its health sector, which was even lower than the percentage of GDP spent by the other small South Asian countries like Afghanistan (10.4\%), Nepal (5.1\%), Bhutan (4.3\%), or the Maldives (6.2\%).40,41 In the same year, about $71.8 \%$ of all health care expenditure in India was paid for privately ( $16.8 \%$ in the United Kingdom ${ }^{42}$ ), with state and central governments contributing $12 \%$ and $6.8 \%$, respectively. 43 This indicates that, with only $3.7 \%$ of GDP being spent on health care, the government's contribution is $<1 \%$ of GDP. ${ }^{41}$

The infrastructure for cancer management is largely inadequate in India. According to the annual report of the Atomic Energy Regulatory Board of the Government of India, till March 2012, 319 institutions across the country had radiotherapy facilities. There were 484 teletherapy units and 343 brachytherapy units at that point of time. Among the teletherapy units, 237 were telecobalt units, and 232 were accelerators. 44 In the year 2007, only 231 institutions had radiotherapy facilities, with 378 teletherapy units and 266 brachytherapy units. 45 So it is obvious that there has been a significant improvement of radiotherapy facilities in the last 5 years, especially in the form of accelerator teletherapy units, of which there were 87 in the year 2007, increasing to 232 in 2012. However, for a population of about 1.2 billion, the requirement of radiotherapy machines is about 1,200 , which clearly points out that the present resources are far from sufficient.

A study commissioned by the American Society of Clinical Oncology (ASCO) in 2008 showed that, by 2020 , there will be 12,500 oncologists available in the USA, and the ratio of cancer patients to oncologists will be 100:1. It was also projected that even if the supply of oncologists were increased by $14 \%$, the requirement for oncologists would increase by $48 \% .46$ This discrepancy in oncologist and patient numbers in a developed country like the US reflects that the ratio is expected to be even worse in developing countries where infrastructure as well as medical facilities are scarce. In Zimbabwe, the nurse to patient ratio in provincial hospitals is $1: 522$, while in district hospitals the ratio may be as high as 1:3,023. Such ratios greatly affect the health care delivery in developing countries. 47

India is classified as a lower-middle-income group country by the World Bank. $4^{8}$ Ninety percent of the oral cancer patients in rural areas belong to the lower or lower-middle socio-economic class, and $3.6 \%$ are below the poverty line based on Pareek's classification. 49 Around $75 \%$ to $80 \%$ of patients with cancers present with late-stage incurable disease and hence increased mortality. $5^{\circ}$ One reason for delayed diagnosis is the lack of easy access to health care, with one study demonstrating a delay of 67.5 days and 53.7 days in obtaining a first appointment for rural and urban patients, respectively. Other reasons included poor socio-economic status of the patient, cost of care, and high rate of illiteracy. ${ }^{51}$ 
Another cross-sectional study on head and neck cancers showed that various beliefs of patients (such as "it is ill-fated to have cancer", "cancer is a curse"), non-availability of transport, ignoring the trivial ulcers in the mouth and believing them to be selflimiting, and prolonged treatment resulting in family stress are important factors in treatment delay. ${ }^{2}$ In addition to inadequate infrastructure, the unequal distribution of health care workers poses a major challenge. The number of health providers per 10,000 population can range from 23.2 in Chandigarh (capital of Punjab and Haryana in the north) to 2.5 in Meghalaya. The majority of the allopathic doctors are located in the south of the country. 53 Within each geographic region, a greater concentration of trained physicians is seen in urban areas (60\%) compared to rural areas. In particular, $74 \%$ of all graduate doctors live in urban areas and provide care to $28 \%$ of the nation's population. Similarly, a disproportionate number of nurses and midwives (four times greater) are located in urban compared to rural areas. 43

\section{FUTURE OF HEALTH CARE SYSTEM}

The major challenge for the management of head and neck cancers is the lower socio-economic class of the majority of the population in developing countries. Along with this, scarcity of infrastructure and health care workers, illiteracy, lack of awareness among the general population about the side effects of tobacco, and prevalent cultural beliefs lead to delays in seeking treatment and, thus, advancedstage presentation of disease.

In response to the increase in the number of cancer patients, new cancer control programs have been implemented in developing countries with the goals of achieving prevention, strengthening the available cancer treatment facilities, and early diagnosis and treatment. 54

The government of India has initiated a national cancer control program to combat the increasing incidence of cancer in India. Oncology units have been developed in 82 institutes in both government medical colleges and government hospitals. There are 246 institutions with radiotherapy facilities across the country. The District Cancer Control Programme has been developed to initiate awareness and early detection activities at the district level. Health education has also been promoted under this program. 39
The need for the future is to have sufficient numbers of trained oncologists and associated medical workers along with infrastructure and government commitment to tackle head and neck cancer as the major disease burden. Along with this, special emphasis needs to be given to prevention programs by the government, as head and neck cancers are potentially preventable.

\section{REFERENCES}

1. Parkin DM, Stjernsward J, Muir CS. Estimates of the worldwide frequency of twelve major cancers. Bull WHO 1984;62:163-82.

2. WHO 2008. The global burden of disease: 2004 update. Available at: www.who.int/evidence/bod (accessed January 27, 2014).

3. International Agency for Research on Cancer. GLOBOCAN 2008 (2010). Available at: http:// globocan.iarc.fr/Pages/fact_sheets_population.aspx (accessed January 27, 2014).

4. Bhurgri Y, Bhurgri A, Usman A, et al. Epidemiological review of head and neck cancers in Karachi. Asian Pac J Cancer Prev 2006;7:195-200.

5. Sankaranarayanan R, Masuyer E, Swaminathan R, Ferlay J, Whelan S. Head and neck cancer: a global perspective on epidemiology and prognosis. Anticancer Res 1998;18:4779-86.

6. Silverman S. Oral Cancer. Hamilton, London: BC Decker; 1998.

7. Graham S. Dentition, diet, tobacco and alcohol in the epidemiology of oral cancer. J Natl Cancer Inst 1977;59:1611-18.

8. Dayal PK, Mani NJ, Bhargava K. Prevalence of oral cancer and precancerous lesions in 'pan'/'supari' chewers. Indian J Public Health 1978;22:234-45.

9. Mehta FS, Hamner JE. Tobacco Habits in India. In: Tobacco-Related Oral Mucosal Lesions and Conditions in India. New Delhi, India: Jaypee Brothers; 1993:89-99.

10. Warnakulasuriya S, Trivedy C, Peters TJ. Areca nut use: an independent risk factor for oral cancer. BMJ 2002:324;799-800. Full Text

11. Gupta PC, Warnakulasuriya S. Global epidemiology of areca nut usage. Addict Biol 2002;7:77-83. Full Text

12. Gupta PC, Ray CS. Epidemiology of betel quid usage. Ann Acad Med Singapore 2004;33:31-6.

13. Agarwal AK, Sethi A, Sareen D, Dhingra S. Treatment delay in oral and oropharyngeal cancer in our 
population: the role of socio-economic factors and health-seeking behaviour. Indian J Otolaryngol Head Neck Surg 2011;63:145-50. Full Text

14. Gupta PC, Sinor PN, Bhonsle RB, Pawar VS, Mehta HC. Oral sub-mucous fibrosis in India: a new epidemic? Natl Med J India 1998;11:113-16.

15. Angadi PV, Rao SS. Areca nut in pathogenesis of oral submucous fibrosis: revisited. Oral Maxillofac Surg 2011;15:1-9. Full Text

16. Rajalalitha P, Vali S. Molecular pathogenesis of oral submucous fibrosis-a collagen metabolic disorder. J Oral Pathol Med 2005;34:321-8. Full Text

17. Jandoo T, Mehrotra R. Tobacco control in India: present scenario and challenges ahead. Asian Pac J Cancer Prev 2008;9:805-10.

18. Murray CJL, Lopez AD. The Global Burden of Disease: A Comprehensive Assessment of Mortality and Disability from Diseases, Injuries, and Risk Factors in 1990 and Projected to 2020. Boston: Harvard University Press; 1996.

19. Jha P, Chaloupka FJ. Curbing the Epidemic: Governments and Economics of Tobacco Control. Washington, DC: World Bank; 1999.

20. Boyle P, Levin B, eds. World Cancer Report. Lyon: International Agency for Research on Cancer; 2008.

21. Patel UA, Lynn-Macrae A, Rosen F, Holloway N, Kern R. Advanced stage of head and neck cancer at a tertiary-care county hospital. Laryngoscope 2006;116:1473-7. Full Text

22. Chhetri DK, Rawnsley JD, Calcaterra TC. Carcinoma of the buccal mucosa. Otolaryngol Head Neck Surg 2000;123:566-71. Full Text

23. Diaz EM, Holsinger FFC, Zuniga ER, Roberts DB, Sorensen DM. Squamous cell carcinoma of the buccal mucosa: one institution's experience with 119 previously untreated patients. Head Neck 2003;25: 267-73. Full Text

24. Lin CS, Jen YM, Cheng MF, et al. Squamous cell carcinoma of the buccal mucosa: an aggressive cancer requiring multimodality treatment. Head Neck 2006; 28:150-7. Full Text

25. Sieczka E, Datta R, Singh A, et al. Cancer of the buccal mucosa: are margins and $\mathrm{T}$ stage accurate predictors of local control? Am J Otolaryngol 2001;22:395-9. Full Text

26. Strome SE, To W, Strawderman M, et al. Squamous cell carcinoma of the buccal mucosa. Otolaryngol Head Neck Surg 1999;120:375-9. Full Text

27. Cruz IB, Snijders PJ, Steenbergen RD, et al. Agedependence of human papillomavirus DNA presence in oral squamous cell carcinomas. Eur J Cancer B Oral Oncol 1996;32:55-62 Full Text

28. Gillison ML. Human papillomavirus-associated head and neck cancer is a distinct epidemiologic, clinical, and molecular entity. Semin Oncol 2004;31:744-54. Full Text

29. Haraf DJ, Nodzenski E, Brachman D, et al. Human papilloma virus and p53 in head and neck cancer: clinical correlates and survival. Clin Cancer Res 1996; 2:755-62.

30. Sisk EA, Soltys SG, Zhu S, Fisher SG, Carey TE, Bradford CR. Human papillomavirus and p53 mutational status as prognostic factors in head and neck carcinoma. Head Neck 2002;24:841-9. Full Text

31. Strome SE, Savva A, Brissett AE, et al. Squamous cell carcinoma of the tonsils: a molecular analysis of HPV associations. Clin Cancer Res 2002;8:1093-100.

32. Kreimer AR, Clifford GM, Boyle P, Franceschi S. Human papillomavirus types in head and neck squamous cell carcinomas worldwide: a systematic review. Cancer Epidemiol Biomarkers Prev 2005; 14:467-75. Full Text

33. Balaram P, Nalinakumari KR, Abraham E, et al. Human papilloma virus in 91 oral Indian betel quid chewers: high prevalence and multiplicity of infections. Int J Cancer 1995;61:450-4. Full Text

34. D'Costa J, Saranath D, Dedhia P, Sanghvi V, Mehta AR. Detection of HPV-16 genome in human oral cancers and potentially malignant lesions from India. Oral Oncol 1998;34:413-20. Full Text

35. Nagpal JK, Patnaik S, Das BR. Prevalence of high-risk human papilloma virus types and its association with p53 codon 72 polymorphism in tobacco addicted oral squamous cell carcinoma (OSCC) patients of Eastern India. Int J Cancer 2002;97:649-53. Full Text

36. Paterson IC, Eveson JW, Prime SS. Molecular changes in oral cancer may reflect aetiology and ethnic origin. Eur J Cancer B Oral Oncol 1996;32: 150-3. Full Text

37. Nandakumar A. National Cancer Registry Programme. Consolidated Report of the Population Based Cancer Registries. Incidence and Distribution of Cancer: 1990-96. Bangalore, India: National Cancer Registry Programme (ICMR); 2001.

38. Ganapati M. India has some of the highest cancer rates in the world. BMJ 2005;330:215. Full Text

39. National Cancer Control Programme - Home: National Portal of India. Available at www.archive. india.gov.in/sectors/health family/index.php?id=11. (accessed April 13, 2014). 
40. Regional Cancer Centre. Updated January 2014. Available at: http://en.wikipedia.org/wiki/Regional Cancer_Centre (accessed January 27, 2014).

41. WHO Global Health Expenditure Atlas - World Health Organization. Updated January 2012. Available at: http://www.who.int/nha/atlas.pdf (accessed January 27, 2014).

42. World Health Statistics 2013 - World Health Organization. Available at: http://www.who.int/ gho/publications/world_health_statistics/EN_WH S2013_Full.pdf (accessed January 27, 2014)

43. Prinja S, Bahuguna $\mathrm{P}$, Pinto $\mathrm{AD}$, et al. The cost of universal health care in India: a model based estimate. PLoS One 2012;7:e30362.

44. Atomic Energy Regulatory Board, Government of India. 2011 Annual Report. Chapter 3: Safety Review of Radiation Facilities. Available at: http://www.aerb. gov.in/AERBPortal/pages/English/t/annrpt/2011/ chapter3.pdf (accessed January 28, 2014).

45. Atomic Energy Regulatory Board, Government of India. 2006 Annual Report. Safety Surveillance of Radiation Facilities. Available at: http://www.aerb. gov.in/AERBPortal/pages/English/t/annrpt/2006/ chapter3.pdf (accessed January 28, 2014).

46. Erikson C, Schulman S, Kosty M, Hanley A. Oncology workforce: results of the ASCO 2007 Program directors survey. J Oncol Pract 2009;5:62-4. Full $\underline{\text { Text }}$
47. Chikanda A. Nurse migration from Zimbabwe: analysis of recent trends and implications. Nurse Inq 2005;12:162-74. Full Text

48. World Bank list of economies. 2013. Available at: http://muse.jhu.edu/about/order/wdi2013.pdf (accessed April 13, 2014).

49. Pareek U, Trivedi G. Manual of Socio-Economic Status Scale (Rural). New Delhi: Manasayan Publishers; 1995.

50. Pai SA. Gutkha banned in Indian states. Lancet Oncol 2002;3:521. Full Text

51. Chintamani, Tuteja A, Khandelwal R, et al. Patient and provider delays in breast cancer patients attending a tertiary care centre: a prospective study. JRSM Short Rep 2011;2:76. Full Text

52. Kumar S, Heller RF, Pandey U, Tewari V, Bala N, Oanh KT. Delay in presentation of oral cancer: a multifactor analytical study. Natl Med J India 2001;14:13-17.

53. Rao M, Rao KD, Shiva Kumar AK, Chatterjee M, Sundarraraman T. Human resources for health in India. Lancet 2011;377:587-98. Full Text

54. Sarin R. Indian National Cancer Control Programme: setting sight on shifting targets. J Cancer Res Ther 2005;1:240-8. Full Text 